\title{
Studies on processing and storage stability of jamun nectar
}

\section{Purandar Mandal, Alok Nath and Bijayalaxmi Mohanta}

Received : $15.12 .2019 ;$ Revised : 10.02.2020; Accepted : 25.02 .2020

See end of the Paper for authors' affiliation

Correspondence to : Bijayalaxmi Mohanta Krishi Vigyan Kendra (OUAT), Jajpur (Odisha) India

Email: bijayalaxmimohanta@ gmail.com
- ABSTRACT : In the study different recipes of Jamun Nectar was standardized to explore the processing potential of Jamun, a minor fruit. There were five different possibilities of recipes. The Nectar prepared from the recipes 20 per cent juice, 14 per cent TSS and 0.30 per cent Acidity gave highest organoleptic quality score followed by Nectar prepared from 20 per cent pulp, 18 per cent TSS and 0.25 per cent Acidity and the quality of the prepared RTS was maintained up to fifth month at ambient temperature.

- KEY WORDS : Jamun, Receipes, Iron, Calcium, Phosphorus

- HOW TO CITE THIS PAPER : Mandal, Purandar, Nath, Alok and Mohanta, Bijayalaxmi (2020). Studies on processing and storage stability of jamun nectar. Internat. J. Agric. Engg., 13(1) : 5255, DOI: 10.15740/HAS/IJAE/13.1/52-55. Copyright@ 2020: Hind Agri-Horticultural Society. 